\title{
Islam without Europe: Traditions of Reform in Eighteenth-Century Islamic Thought
}

\author{
Ahmad S. Dallal \\ Chapel Hill, NC: The University of North Carolina Press, 2018. \\ 436 pages.
}

It is hard to exaggerate the scope or scale of this major monograph from one of the foremost Arab Muslim scholars of his generation, Ahmad Dallal, formerly Provost at the American University of Beirut, and now Dean of Georgetown University Qatar.

In carefully orchestrated arguments, with massive documentary evidence, Dallal addresses eighteenth century theological/juridical issues across the span of the Muslim world. He touches on intellectual giants and reform movements from Senegal to Syria, from Yemen to India, delving deeply into complex debates that continue to resonate. Islam without Europe catapults Dallal into the company of revisionists who are also global historians, those looking for a way to redefine Islam outside the parameters of European historical conventions.

The structure of this book neatly unfolds its several subsets. The Introduction is followed by five chapters and a Conclusion. Each chapter is marked by meticulous scholarship, but even more by a bold thesis: reform was largely generated within Muslim intellectual circles, devoid of influence or dependence on European action or actors. Dallal reviews seven major figures from different parts of the Arab/Muslim world. Collectively, they emerged as representatives of change, coded as ijtihäd and opposed to taqlid. He demonstrates how the oeuvre of these disparate intellectual giants calls into sharp question both the notions of decline (not just from Bernard Lewis but from experts on the eighteenth century) and accommodation, or responsive adaptation, to Western (that is, West European) notions of truth and tradition.

While Dallal reviews the scholarship of others fairly, and often critically, he moves beyond criticism to a reconstruction of the world-view characterizing these preeminent scholar/activists. In the Introduction he sets the bar high for all that is to follow when he asserts that the breadth of originality and the degree of radical reflection among these eighteenth century Muslim intellectual giants "demonstrates an originality and radicalism... that was hardly equaled in any other period of Islamic history" (19). 
It is impossible to do adequate justice to Dallal's superb analysis of these giants. They include: Muhammad Ibn 'Alī al-Shawkānī, 'Abd al-Ghanī alNābulsī, Muḥammad Ibn Ismācīl al-Ṣanānī, Muhammad Ibn 'Alī al-Sanūsī, 'Uthmān Ibn Fūdī, and Shah Walī Allāh al-Dihlawī. Each chapter offers evidence and marshals arguments that tackle the range of issues marking Muslim engagement with challenges in local contexts from West Africa to South Asia. Their elective affinity, together with their longstanding scholarly networks, make these thinkers extraordinary points of light. Not only do they reflect, they also redefine an emergent anti-colonial Muslim world. It is a world shaped as much by its own inner logic as by the external challenges from a massive European intervention that, in time, narrowed the future for these individuals, as also for Muslim society at large.

Dallal's, it should be stressed, is not a nostalgic but a recuperative project. It ranks with its revisionist precursor, Dipesh Chakrabarty's Provincializing Europe: Postcolonial Thought and Historical Difference (Princeton, 2000), in demonstrating how 'local' knowledge has global connections: its exponents are sensitive at once to the changes in their world but also the need to be custodians of tradition.

In his prior books Ahmad Dallal achieved renowned for his contributions to the study of Islam and science. Here he enters into a neighboring but discretely separate domain: religious/juridical studies. Though an autodidact, he scales new heights and makes stunning advances. He begins by highlighting the pivotal role of Muhammad Ibn 'Abd al-Wahhāb. With his strict accent on tawhìd, Ibn 'Abd al-Wahhāb could, and did, "argue that even someone with great love for God may be an unbeliever" (25). Initially some of the other eighteenth century reformers wrote poems in praise of Ibn 'Abd al-Wahhāb, but they were retracted since "in contrast to Ibn 'Abd al-Wahhāb, all the other major thinkers of the eighteenth century managed to formulate meaningful, often strict, codes of social behavior and religious practice without condemning Muslims and falling into the trap of takfir" (55). In reimagining the eighteenth century, one needs to revisit ijtihād and, as Chapter 2 signals, explore "the regional origins of a universal vision," often forged in networks linked through the Hijaz and the Two Holy Cities. Integral to ijtihād was a revised but still robust form of Sufism, at once Old and New, outlined in "the multiple faces of the spirit", made visible in Chapter 3. None was immune to politics, but collectively they exposited a "politics of knowledge" based on "genealogies of dissent", the subject of Chapter 4. This project could not have succeeded, however, without "humanizing 
the sacred", in this case, by resort to innovative approaches to hadith scholarship, not minimizing the importance of the Prophet Muhammad in his time but extrapolating lessons from the formative era that could be, and were, applied to the contemporary era and its challenges.

And those challenges persist, which makes this book all the more important today. Instead of passivity there is the need for creativity; not despair but hope marks the moment. How does one rethink the umma and reimagine Muslim life? It is through attention to the zeitgeist in each generation, and that is the link (the crucial link) between the eighteenth and the twenty-first centuries. In Ahmad Dallal's own words,

what this book has sought to capture is a glimpse of the remarkable spirit-at once original and radical-of the eighteenth century as defined by intellectual giants of Islamic thought from diverse regions of the Muslim world. It is only to the extent that we can recuperate their vision in their own words, and within their own epistemic paradigms, that we can begin to imagine the relevance of their reform projects to today's Muslim communities. (321)

It is not an easy task, but it is a crucial, and creative, step toward revalorizing history as a tool of social dynamics across time and space, across race and class barriers. All the arguments and evidence of this masterpiece compel a reassessment of Islamic civilization and the indispensable function of intellectual networks.

Islam without Europe will have at least three audiences. It should appeal to a broad readership in several subsets of history: first in Islamic, but also regional, trans-regional, global, and finally comparative history. Secondly, it can be, and should be, an indispensable resource for students of Islamic intellectual thought, whether social scientific or humanistic in their outlook and labor. Thirdly, it is too valuable to remain a merely academic book. Its writing is lapidary, its arguments cogent and compelling, to a degree that make Islam without Europe of general interest to all public readers who want to grasp the breadth and subtlety of the Islamic engagement with reform. Islamic reform can at last be seen for what is: an ongoing, internal process, apart from the demands, and beyond the claims, of Western modernity. 